PP Periodica Polytechnica
Architecture

48(1), pp. 35-44, 2017

https://doi.org/10.3311/PPar. 10608

Creative Commons Attribution (i)

RESEARCH ARTICLE

\section{Spatial Formation in 16-19th Century Calvinist Church Architecture: The Calvinist Churches of Sepsiszék}

\author{
Dóra Danielisz $^{1 *}$
}

Received 10 February 2017; accepted 01 April 2017

\begin{abstract}
One of the less-known and less researched regions of the Carpathian Basin is Sepsiszék, which as part of Háromszék County, was one of Greater Hungary's southeastern frontier-guard areas. After the Reformation, the population of the region became almost exclusively the followers of one of the Protestant tendencies with Calvinism gathering the most members. Due to the location of the area, Sepsiszék and its vicinity - the former territory of the county - is home to Europe's easternmost Protestant communities to this day. Thanks to the unique cultural, religious and social environment, the unique development of local church designs notably enriches the history of Protestant religious architecture.

The survey documentation of the area's 32 Calvinist churches along with the schematic analysis of architectural history was carried out during the summer of $2015 .^{1}$ The central question of the research was how did the assessed churches accommodate the spatial demands of the new liturgy, and what tendencies can be identified regarding the shaping of the space. The interior layout, galleries, additions to the buildings, the proportions in the floor plans and spatial ratios will be the topics through which these questions will be answered. After tracing the locally observable main characteristics of Protestant spatial formation, similarities with Hungarian and international examples will also be explored.
\end{abstract}

\section{Keywords}

Calvinist, Protestant, church, architecture, Transylvania, Sepsiszék, Háromszék, Covasna

\footnotetext{
${ }^{1}$ Department of History of Architecture and of Monument Preservation, Faculty of Architecture, Budapest University of Technology and Economics 1111 Budapest, Müegyetem rkp. 3., Hungary

*Corresponding author, e-mail: danieliszdora@gmail.com
}

1 The results of the research were first published as part of a Scientific Students' Association's Paper: Danielisz, D. 2015.

\section{Introduction}

The historical Háromszék county holds a unique place in the history of European Protestantism. After the inhabitants of the area became, almost exclusively, followers of one of the Protestant tendencies. After the initial successful achievements of the Lutheran Reformation, Unitarianism and finally Calvinism found followers in largest numbers. A close cooperation can be witnessed between the latter two Protestant trends in the county throughout the centuries, being also a unique phenomenon in a broader, European context. ${ }^{2}$

This paper examines the 16-19th-century events of the Protestant church architecture of a smaller area within the county. In the light of the results of the research and on-site explorations carried out on 32 Calvinist church buildings in the former Sepsiszék, the formation and progress of liturgical spaces are studied through architectural means and the analysis of space-use.

Thanks to the relative isolation of the area, these churches were able to conserve the stages of the local developments of liturgical spatial design throughout several hundred years, uniquely contributing to the expansion of the global knowledge base in Protestant church architecture. Naturally, the architectural image of this small area is not homogeneous; however, the distinctive architectural tendencies in spatial design can be clearly seen along with the characteristics of the universal architectural development of Protestant churches. A particular value of the area's church architecture is the strong fidelity to traditions, because “... Calvinist churches (...) represent the continuity in the tragic break in traditions during the 16th century".

\section{The Architectural Tools of Spatial Formation}

The main development stages of liturgical spaces are interpreted by presenting the architectural tools of spatial design. The purpose of each tool is to shape the given space to fulfil the needs of the liturgy and also the users. It can be concluded that

2 The establishment of the so called "Rikánbelöli Kommunitás".

3 “...a református templomok (...) a folyamatosságot képviselik a tradiciónak a XVI. század folyamán bekövetkezett tragikus megszakadásában.” Marosi (1992 p. 26.) 
the main goal is the centralization of the space and holding on to some kind of hierarchy in the interior.

New phrases should be introduced: the additive and the constructive architectural tools. Additive tools are architectural interventions altering the space, but keeping the previous traits of the building, only adding some new elements, thus helping to centralise the space. Such additive tools are furnishing elements, galleries and building additions. Constructive tools are all alterations that require either the partial demolition of a building, remodelling, or erecting a completely new church. The two methods, of course, are not sharply separable, although it is necessary to accentuate the difference between the further building of former buildings and creating new spaces.

\subsection{Church Furnishing and Liturgical Space Use ${ }^{4}$}

The centre of a Protestant churchgoer's attention is the testament and the preaching. This fact is key in revealing the inner logic of the buildings to be discussed. The orientation of the space is defined by a special centre: the place where the preaching is practised. This principle parallels with the scientific view of the known world at the time.

The centre of the Calvinist liturgical space is the pulpit ${ }^{5}$ and the Lord's Table located at the 'market of the church'6. According to the most common custom, the pastor's seat, the so-called Moses chair is located at the northern wall of the church, next to the pulpit. The seats for the congregation are facing this centre area defined by the pulpit and the Lord's table. Most churches include one or more galleries, most likely with an organ. During the centuries before the presence of such instruments, the ceremony was accompanied by singing. The cantor's place was the "singing chair", which was most likely located at the market, or the gallery. ${ }^{7}$

It may be logical to think that, during the 16 th and 17 th centuries, the accessories of the Catholic liturgy, the "forbidden" imageries, were removed from churches; however, routine and tradition often contradict Calvinistic theology. As can be read in the case of the church of Fotosmartonos, in a decanal visit report from 1735, that among others "Insuper the confessional and other substances are in the church sine diminution".

4 More on the topic of seating patterns and spatial use: Danielisz (2016)

5 In the old decanal visit reports (Buzogány and Sipos, 2005) the Hungarian-Latin word 'pulpitus' can be found. It is the very same word as the English 'pulpit', but has another meaning. It is referring to the singing pulpit, where the cantor stood. In these reports, the word 'cathedra' is used instead of pulpit or pulpitus

6 'Market' in Hungarian, in this area of the county, this is phrase describes the central area in the church to which the liturgical space design is oriented.

7 According to the decanal visit reports (Buzogány and Sipos, 2005), most churches had a singing pulpit, however, to the present day, the use of such appliance has completely vanished from practice. More information on the Transylvanian singing pulpits: Ösz (2008), Mihály (2008)

8 “Insuper a templomhoz való gyóntató és egyéb substanciák megvannak sine diminutione.” Buzogány and Sipos (2005 p. 104.)
From this, it may be concluded that the rural congregations, especially, kept several Roman Catholic traditions even in the 18 th century, such as confession and that old furnishing and equipment were not completely discarded. Another example of the devotion to archaic practice, habits and objects is the seating order in the church.

The insides of the reformed village churches should be seen as a small duplicate or model of the village itself. The previously mentioned phrase: the church's market also refers to this circumstance. Through this, the structure of the social hierarchy is readily discoverable. The Sepsiszék area holds a relatively unified custom or practice; only its borderlands show some exceptions.

In most cases, the churches have two entrances, one on the western and one on the southern side. These entrances mark out two axes within the church building; their intersection is where the market is located.

According to the most common practice, when entering the church through the southern gate, the main entrance, standing across from the pulpit on the northern wall, the men's side is on the right-hand side. This side was once the sanctuary, or a closure symbolically imitating a sanctuary. Women enter the church through the western entrance, and they are seated at the western half of the church. The wife of the pastor is seated at a particular spot among the women, usually in the front row, on the first seat. If there are seats opposite the pulpit also facing the pulpit, these are the reserved seats for decorated individuals, elderly men, presbyters, guests and confirmands; at special events like a wedding or christening, these seats are reserved for the corresponding families.

A centralising seating order (Fig. 1) can be found in most of the churches in the area. The centre of the liturgical space - depending on the layout of the church - is marked out by the pulpit located on the triumphal arch or at the middle of the northern wall of the building. Fine examples of this centralising layout are the churches of villages Bita and Sepsiszentkirály. Slight variations of this type can be found in the churches of Málnás and Sepsibesenyő, where the entrances are on the eastern and southern, or on the northern and western sides of the church respectively. The men always use the entrance on the transverse axis.

However, there are churches in Northern Sepsi which preserved the longitudinal layout. Typical examples of the use of the longitudinal axis are the churches in the villages of Oltszem (Fig. 2) and Bodok. In the case of Oltszem, the previously mentioned scheme also applies with a longitudinal layout: standing opposite from and facing the pulpit, the men's seating is on the right while the women are seated on the left. In the case of the church in Bodok, an imaginary plane stretches between the transverse axis defined by the southern entrance and the triumphal of the sanctuary. This plane divides the interior into three sections. According to this division, the section furthest from 
the sanctuary, the one on the right-hand side of the southern entrance is where the women are seated. The middle section, closest to the section of the sanctuary is the place for the men. The third section, the sanctuary itself, maintains a centralising layout: the furnishing and appliances used during the liturgy as well as the seats of the pastors and presbyters are located around the Lord's table in a concentric layout.

Thus, the reorganisation of the layout played an important role in the rebirth of the reformed church interiors but possibly holding the deepest hierarchical order as well.

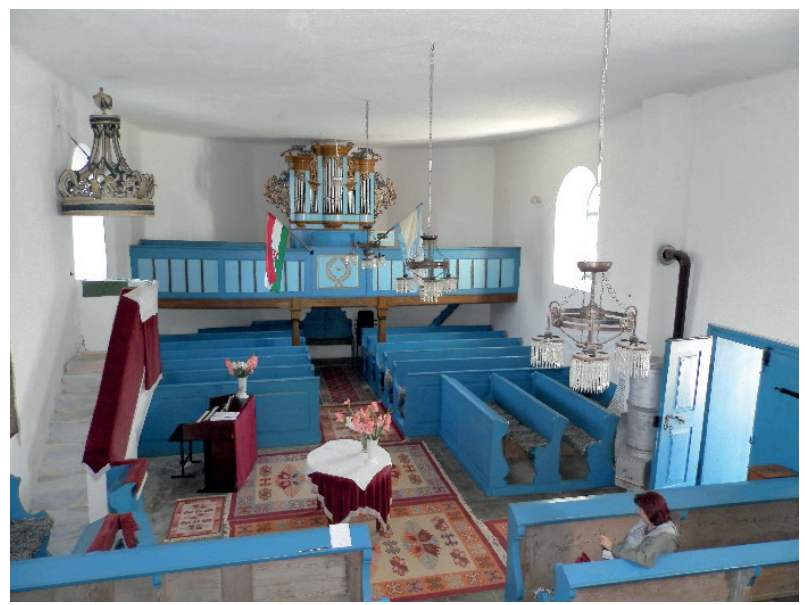

Fig. 1 Calvinist church of Fotosmartonos. An example of the centralising seating order. (2015)

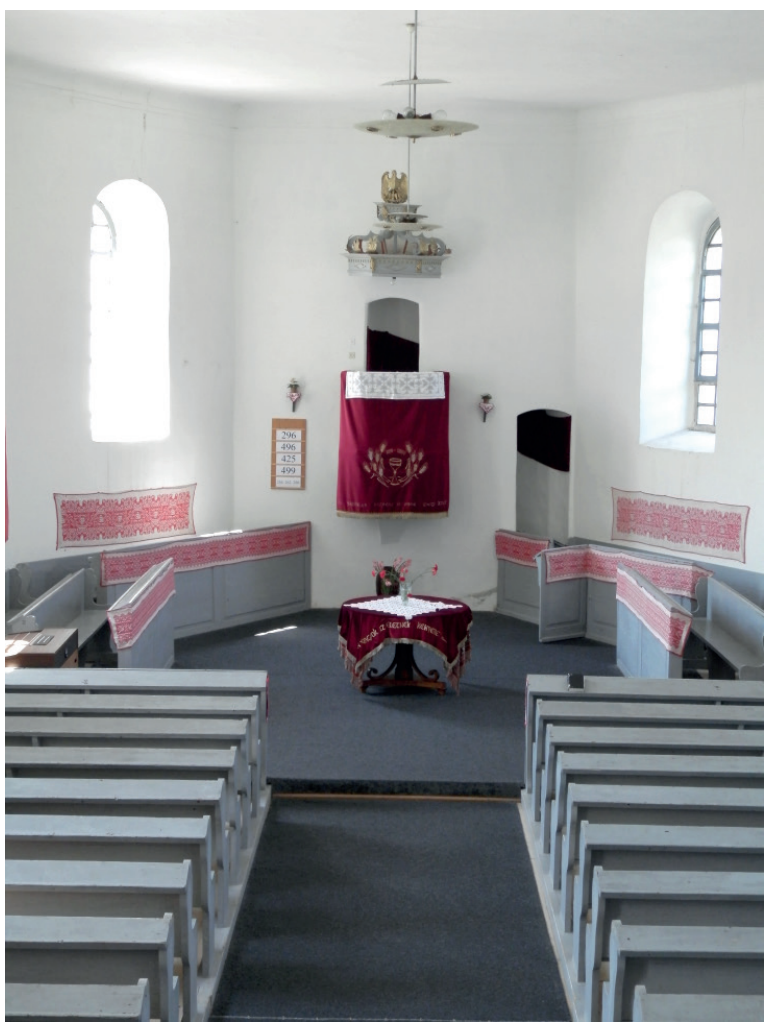

Fig. 2 Calvinist church of Oltszem. An example of the longitudinal seating order. (2015)

\subsection{Galleries as Interior Shaping Elements}

Galleries are typical elements in shaping Protestant church interiors, occurring in a wide variety of forms. Beyond the simplest baronial or aristocratic galleries, the unmarried young men's galleries, and organ galleries, there are many more complex ones. Capable of significantly shaping the interior, there are multi-storey galleries (the Calvinist church of the village of Szentes), "L"-shaped (Magyarhermány) and "U"-shaped galleries (Lutheran church of Brassó), and ones that stretch around the whole interior (Huguenot meeting house in Charenton). Here, in the area Sepsiszék, focusing on today's conditions, galleries and their structural methods do not show such scale of diversification. However, it cannot be concluded that the current circumstances are the same as in previous times.

As of today, the typical galleries of the discussed area are structures spanning across the church transversally, bridging across the whole width of the building. A remarkable exception is the gallery of the church in the village of Réty (Fig. 3), where the gallery is located in a separate extension of the building on the southern side.

Examining the galleries from an interior-shaping point of view, there is a tendency towards centralising the liturgical area of the Calvinist church. Typically, the galleries placed on both ends of the church hold such an impact that the space "trapped" between them seems even more central. Another way of looking at this is if we take the well-known three-naval church layout, but rotate it 90 degrees. ${ }^{9}$ This act drives the attention to the middle, double-storey space, squeezing its proportions. The galleries, especially if their shaping is solid, dense as the one in the Egerpatak church, or relief-like as in Zoltán, create a kind of interior facade, bringing closer the transversal ends of the church to the centre. A fine example of the gallery's role in altering the interior space is that in the church of Sepsimagyarós, where due to the placement of the galleries, the middle, two-storey space seems as a perfect square from each side, thus helping to emphasise the centralising layout and use of space. The accessibility from three sides and the additions to the building further enhance this impression, which further shows a relation with the "T"-shaped use of space.

Despite the previously mentioned contemplations, it is obvious that the given buildings with their interior spaces are purely functional. The congregation's growth in numbers and the appearance of the organ required the building of galleries in order to gain more floor space.

9 According to István Bibó, the use of galleries in single-naved churches is unfavourable (Bibó, 1984, p. 4.), however in three-naved Protestant churches, placing galleries above the side naves is advantageous (Bibó, 1967 p. 535.). If the discussed churches are to be imagined as transversally three-naved spaces, then this layout could be even more favourable regarding Protestant church buildings than the longitudinally three-naved layout, as it further amends the space towards a centralizing spatial ideal. 


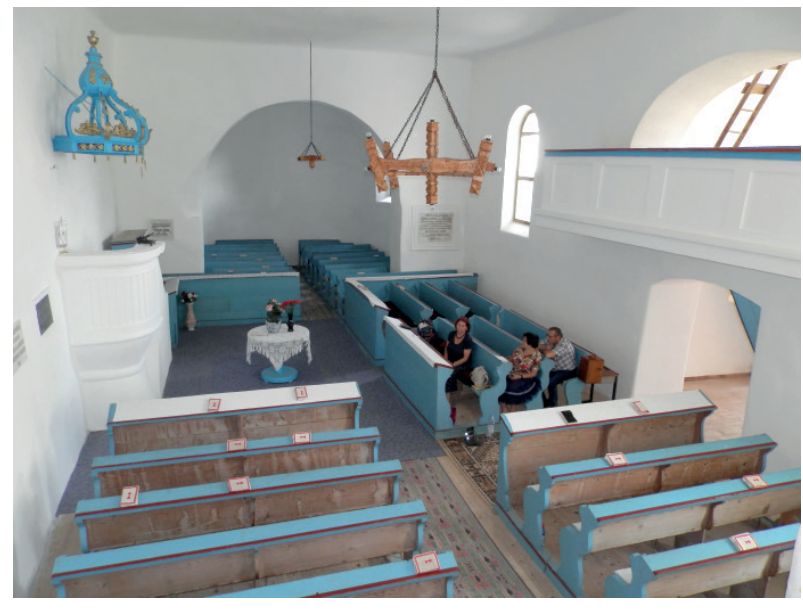

Fig. 3 Calvinist church of Réty. An example of the gallery as an interior shaping element. (2015)

\subsection{The Additions to the Building and their Effect on the Layout}

The transversal axis - mostly generated by functional layout reasons inside the church - sooner or later had to be architecturally shown on the exterior facade as well. Also, because as mentioned previously, this became the church's main entrance in most cases after the Reformation. In the case of churches from the end of the 19th century, in the spirit of historicism, these are merely framings around openings. Generally, it is observable that throughout Transylvania, the shaping of these southern additions or porticos comes in a great variety. Beyond the southern church halls or porticos, placing the stairwell leading up to the gallery in an exterior addition to the building is common as well as using building additions as mortuaries.

The southern additions are exclusively important in this case, since these porticos developed into more accentual architectural elements, transforming into bell towers in the 19th-20th century. This resulted in demolishing the former wooden belfries, or these southern additions became multi-story, more voluminous structures with a role complementing the liturgical space. In the Sepsiszék area, an example for the latter direction is the village of Réty's Calvinist church.

In the case of Réty (Fig. 3, Fig. 4), the pews continue in the single-story southern addition, representing the continuation of the liturgical space in this transversal addition. This, and the galleries placed on the longitudinal ends of the building, enabled the church to be used in a more transversal direction. In many Calvinist churches of Háromszék county, the " $T$ "-shaped use of space is noticeable. More characteristic examples of this kind of space use is the church in Dálnok. Here, the bell tower on the south side of the church includes two stories of pews above each other; or the church in Köpec, where the addition to the church building on the south side is the same height as the church itself, marking out the transversal axis of the use of space.

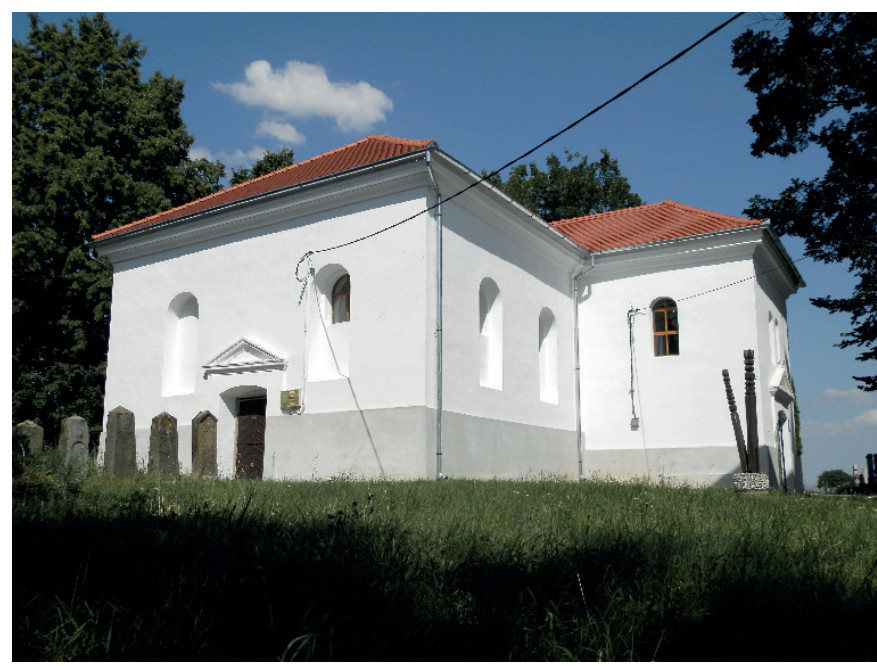

Fig. 4 Calvinist church of Réty. Example for the „T” shaped layout. (2015)

This architectural solution, involving a southern addition to the liturgical use of the church is presumably a spontaneous act generated by the centralising liturgy. However, the interesting aspect is, that probably independently, western Protestant church architecture came to the same conclusion. Leonhard Christoph Sturm made interesting attempts at the beginning of the 18th century to introduce transversal space use in Protestant church architecture. His ideas most probably came from practical solutions found in German and Dutch churches. The most important example of the " $\mathrm{T}$ " shaped layout in Hungarian church architecture is the Reformed Great Church of Debrecen.

It is a very important idea that both vernacular and high architecture came to the same conclusion in defining an ideal Protestant church layout. Village churches took on the layout and spatial form appropriate to the spatial needs of the liturgy during an organic evolution, which also shows that the liturgical space is shaped by the liturgy itself.

\subsection{Proportion and Shape}

The transformation of the liturgical spatial situations and the proportions of the spaces is a spectacular, but obviously very slow process. This transformation can be illustrated by following through the stages of the whole time interval in chronological order.

Romanesque-age buildings in their complete form cannot be found in Sepsiszék. The small village churches of the time became the victims of the 1241-42 Mongol invasion of Europe or were reconstructed during the Gothic era. The 13th-century sanctuary of the church in Réty may provide a picture of the age when such churches - with semi-circular or straight recesses dominated in the area. The earliest complete churches are from the Gothic age.

If the spatial proportions of these medieval churches are to be examined, the results are that in terms of the floor plan, the 


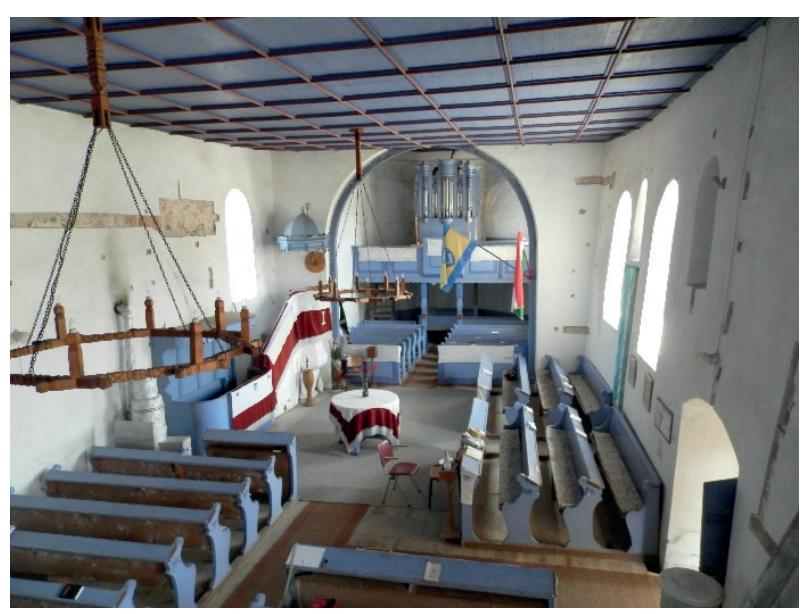

Fig. 5 The Calvinist church of Gidófalva. (2015)

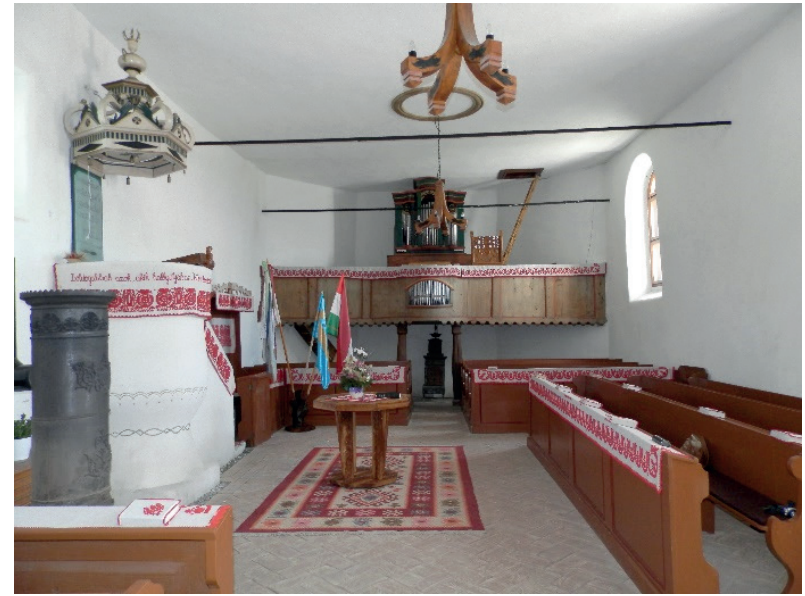

Fig. 6 The Calvinist church of Kálnok. (2015) proportional number comparing the length and width of the nave is around $3.1-3.25$. In terms of the cross-section, the height of the inside of the church compared to the nave's width, the ratio is around $0.7-0.9$. These ratios also show that the mentioned buildings are Gothic churches. ${ }^{10}$ (Fig. 5)

The decay of Gothic churches occurred slowly throughout the centuries. The Turkish and Mongol invasions from the 16th -18th centuries, as well as the 1612-13 Saxon and Rascian raids, resulted in the devastation of the Gothic churches. During the 1699 Reunion of Hungary and Ferenc Rákóczi's Independence War, many more churches were burnt down. However, Medieval churches that survived these times cannot be found in their original form, their original shape was made mostly unrecognisable during the 19th-century reconstructions. The gradually decaying Gothic churches were slowly replaced by new Calvinist churches during the following ages.

The next group comprises of churches that were built or rebuilt not long before the Reformation, but not after the first quarter of the 18 th century. These buildings are mostly from the time when the inhabitants became followers of one of the Protestant religions. This category includes the Calvinist churches of Szacsva, Kálnok (Fig. 6), Kilyén, Árkos and Aldoboly, of which the last three were certainly built for Calvinist congregations. Thus, the latter three churches are worth analysing in more depth.

Considering the churches from a proportional point of view, there are no changes compared to previous ages. The length/ width ratio is still around $3.0-3.5$, the ratio between the height and width of the nave is around $0.75-0.85$. The change is not in the proportions, rather in the layout. The churches from the time are also east-west oriented, the exterior shape of the sanctuary often has a polygon layout, but on the inside, the sanctuary is merely a symbolic recess; it is not separated from the

10 Gothic church types from Sepsiszék: Gidófalva, Lisznyó, Sepsiszentgyörgy, Sepsibodok. nave by a triumphal arch, nor is it narrower or shorter in height from the main nave. Presumably, the polygonal recess of the sanctuary and the Gothic proportions were the embodiments of the perfect church for the believer of the time; however, the interior and the layout is centralising and organised around the pulpit. The usual Gothic principles in the layout such as a longitudinal axis, or a furnishing layout drawing the attention towards the sanctuary are no longer found. This period is somewhat obscure, and very few sources are available, even though this period would be the most important in understanding the transformation of the medieval church-type due to the effects of the Reformation.

The 1781 Patent of Toleration, gave a new nationwide momentum to building new churches. The buildings linked to this period are the Calvinist churches of Illyefalva, Zoltán, Angyalos and Kökös villages. These churches were built between 1782 and 1803. Considering both the years they were built and their shaping, they clearly represent the effect of the Patent. During this period, the church of Illyefalva (Fig. 7) could have been exemplary in the area due to its size and the settlement's status: the settlement was a borough by rank.

Examining the length/width ratio of the churches, it can be concluded that the stretched Gothic proportions somewhat narrowed to a ratio around $2.0-2.5$. The nave's height-width ratio is around $0.6-0.7$, showing more "compressed" interior spaces regarding height. The evolution can be clearly seen in the proportions and ratios. However, the mentioned churches of the period still carry on the sanctuary form at the end of the nave. In the case of smaller churches, this could be the influence of the church in Illyefalva.

It is known that the Calvinist church of Illyefalva was built according to architectural plans led by a master builder between 1782 and 1785. There is no information in related literature about the origin and designer of the plans, nor the name of the builder. According to the author, the finished building carries a Roman Catholic influence as well as a local tone. 


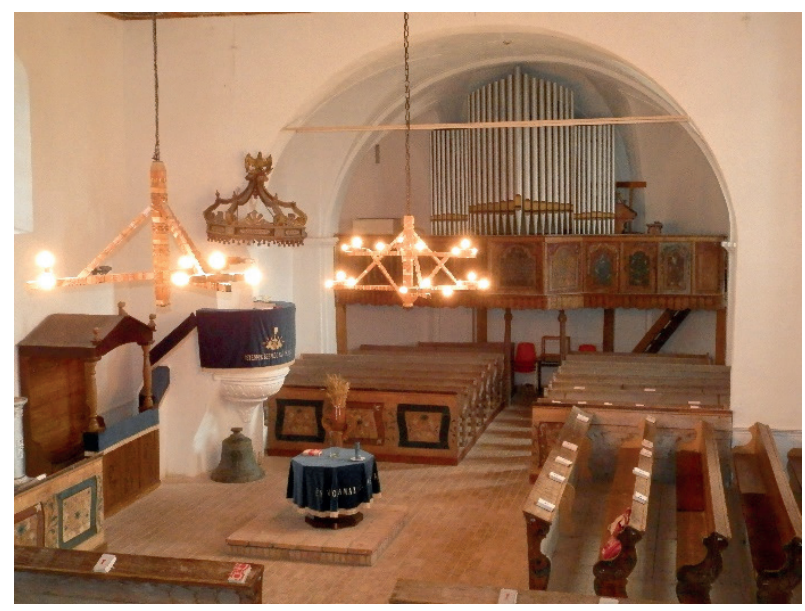

Fig. 7 The Calvinist church of Illyefalva. (2015)

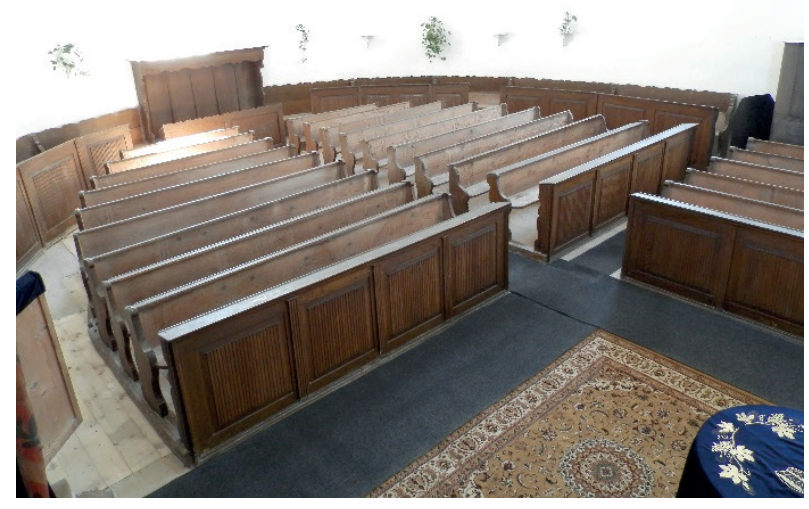

Fig. 8 The Calvinist church of Bikfalva. (2015)

The "Patent of Toleration-type churches" apparently regained a sanctuary or apse in their architecture, which caused some disturbance in the layout of the interior. As seen in the previous Gothic churches, the pulpit is often placed at the triumphal arch or in the traditional place of the altar, in the central axis. The sanctuaries of these churches are mostly vaulted, and although making the interior more diverse, they can be more related to the Roman Catholic church form and interior layout.

The churches of the next period, between 1808 and 1863, give up on the medieval tradition of sanctuary and become almost exclusively centralising spaces by the end of the period. Such buildings are the Calvinist churches of Bita, Szotyor, Fotosmartonos, Málnás, Szemerja and Bikfalva. The churches of Oltszem and Uzon, although belonging to this period and trend, still stick out with their stretched floor plan. It is known that both churches were built on former Gothic church's foundations and ruins. This is the most probable reason for the compared to the period's trend - unusually elongated shape of the named churches. This period can be better reviewed through analysing the above mentioned six churches.

The layout proportions of the churches - in the usual context - are between 1.9 and 2.25, the nave height-width ratio is around $0.5-0.7$. The inside of the church becomes more and more functional. The first three churches - from the beginning of the period - only keep the polygonal recess of the sanctuary; the proportions of their layouts are a transition between the churches built during the time of the Patent of Tolerance and the ones built at the end of the current period. Looking at the floor plans of the latter three churches, built between 1853 and 1863, and especially in the case of Bikfalva (Fig. 8), it can be clearly seen how far they have come from the Gothic proportions. The tradition, which requires the church to have an accentuated polygonal recess at one end is still obstinately compelling. In the case of Bikfalva, this eastern sanctuary-imitation is a semi-circular recess from the inside and the wellknown polygonal solution from the outside.

In the churches of Málnás and Szemerja, a kind of articulation appears on the interior walls of the liturgical spaces. Double pilasters, with distinctive capitals or pilasters and half-columns in groups of four, divide the wall planes and thus the interior in an even rhythm.

The church in Szemerja carries a coffered ceiling, which is a suspended structure due to its age (1992) and its dimensions (a span of around 13 metres). The Málnás church seems to deceive the observer by imitating vaulting above the nave. Although the attic area is covered with flooring, thus not showing the real structure under it, it is presumable that the nave is covered with a wooden vault system - being a popular structure at the time.

Getting closer to the turn of the century, two churches built in a historicising manner should be introduced. The churches of the villages of Maksa and Sepsiszentkirály, built between 1879 and 1900, are the examples describing the period. The low number of churches indicates the end of the time of great church constructions in Sepsiszék. The ratio between the length and width of the nave varies between 2.17 and 2.26 and is in the range of 0.6 to 0.8 regarding the nave's height/width. This shows a kind of stagnation in numbers.

Regarding the design of the buildings, the church in Maksa (Fig. 9) can be associated with the previous period, the historicising manner rather appears in the decoration. The interior has a rhythmic articulation achieved by pilasters, but in this case, they are not only imitated pillars. The pilasters along with the external buttresses imply a former vaulted structure, which was damaged by 20th-century earthquakes to a degree that it collapsed during the 1986 earthquake along with the western gallery. It was replaced by a suspended ceiling.

From outside, the church of Szentkirály could easily be confused with a Roman Catholic church. Its accentuated bell tower on the western facade, the buttresses along the walls and the lack of a portico on the southern side all seem to amplify this similarity. The sanctuary appears again in the design of both the exterior and interior, which is oriented North and is one of a kind in Sepsiszék. The presumed reason for this is the structure of the village-scape: this late building had to find a place along 
the main street among the narrow plot strips; thus the orientation was most likely predetermined.

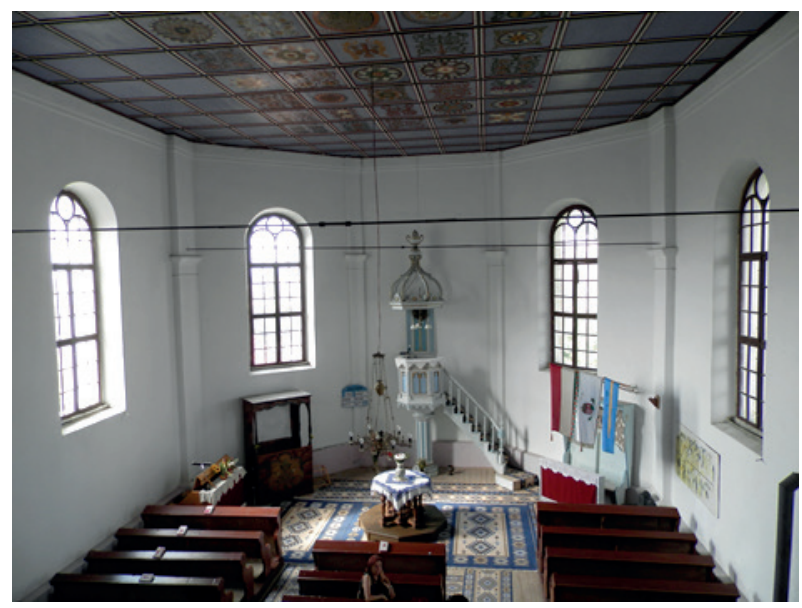

Fig. 9 The Calvinist church of Maksa. (2015)

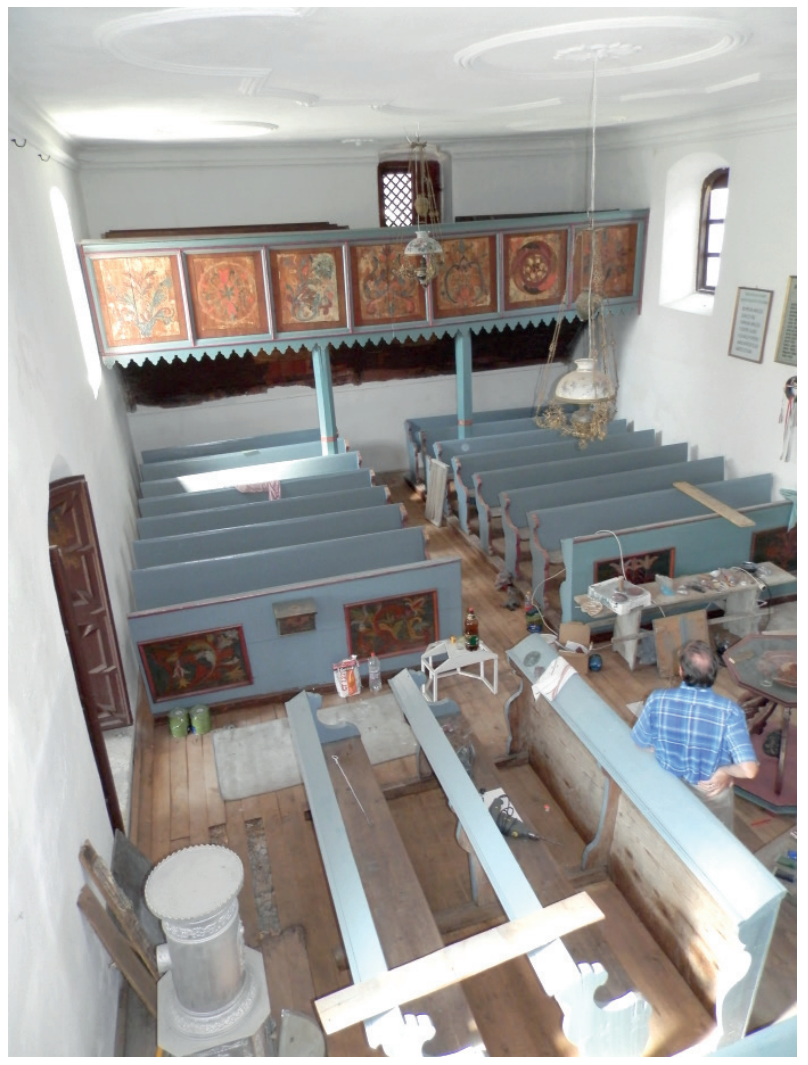

Fig. 10 The Calvinist church of Sepsimagyarós. (The painted furnishing under examination, 2013)

The reason why these late churches reached back to the traditions of church architecture of the middle ages, could be the historicising trend of the time, as well as the connections of the Transylvanian Hungarian Reformed Church with Northeastern Europe: including English, German, Swiss and Dutch relations. The strong stylistic influence flowing in from mostly German and English grounds at the time, as well as the new policy of the German Protestant church architecture, favoured and preferred the Gothic style. The principles of John Ruskin and Auguste Charles Pugin and the effect of the Neogothic style of Schinkel became written guidelines for the Protestant church architecture in the Eisenach Regulativ. This writing had a decisive impact on Central Europe's Protestant church architecture in the second half of the 19th century, thus on Hungarian regions as well.

The last church type from the timeline to be discussed is the church with a rectangular layout. The length/width ratio of such rectangle-type buildings are between 1.77 and 2.51; this number is between 0.6 and 0.9 regarding height-width. These numbers visibly vary over a wide range; the scale runs from Gothic proportions to fully centralising forms. The 1.77 ratio between height and width, describing the proportions of the church of Zalán deserves special attention. This interior, bordered by two transversal galleries, shows a completely centralising effect not only because of the appliances and furnishing but also due to the spatial proportions. From this point, the distinction between churches built originally in this form and churches later reconstructed in this manner is necessary.

Churches originally having a rectangular floor plan were built between 1756 and 1820, but mostly after the Patent of Tolerance. Such churches are found in Sepsimagyarós, Étfalva, Eresztevény and Sepsiköröspatak. It is a truly noteworthy act that these small churches, breaking the habit of the polygonal recess of the nave - the tradition of having a sanctuary - could give up on such Catholic attributes that were not in accordance with the liturgical use of space.

It is fairly unusual that the church of Sepsimagyarós (Fig. 10) - earliest among the rectangular type, between 1746 and 1752 (Buzogány and Sipos, 2005 pp. 185-189) - could be built, despite the anti-protestant political trend of the time; furthermore, having such a functional floor plan.

Churches that were reconstructed to a rectangular shape are those in Zalán, Komolló and Sepsibesenyő. The reconstruction works occurred between 1821 and 1887; the original core of the building in each case dates back to the late 13th century or the early 14th century. When defining the new layout, the previously mentioned four early rectangular-type churches could have been a model for the builders being nearby in both time and location. The extension of the churches was performed in an East or Southeast direction, resulting in the demolishing of the medieval sanctuary. That the polygonal sanctuary-form was not a chosen solution during the reconstructions could be due to financial reasons and western influences along with the direct antitypes. With reference to either the early or late examples of the rectangular-type churches, a common attribute is the vast simplicity of the interior, which, beyond the strict layout, is caused by the plain flat ceiling above the nave.

The churches of Egerpatak and Réty have been excluded from the examined group of churches. The reasons for this vary. The layout and structure of the church in Réty are very special. When analysing the galleries, the main virtue, the gallery of the church has already been mentioned. The church in Réty and 
further " $T$ "-shaped churches of the neighbouring Háromszék play an outstanding role in the context of liturgy and design.

Regarding Egerpatak, the exact date of the building remains unknown. What is certain, is that it was a former Filial of Szacsva. Based on the age of the roof structure ${ }^{11}$, the church was presumably built in the early 18 th century. This idea is supported by the belief that the church is probably the same age as the church of Sepsimagyarós, similarly detached from the Szacsva parish.

Beyond the 32 churches discussed, other buildings worth mentioning are those that were closely associated with the culture of church architecture but are lost in the shadows of the past. In the evolutionary progress, important stages could have been those wooden churches and meeting houses that were the predecessors of today's churches in Kökös, Bita, Fotosmartonos or Sepsiszentkirály.

Their design and shape were most likely defined by - beyond the adequacy to the liturgy - the strict construction rules of wooden architecture and the high-quality woodworking traditions specific to Transylvania. There is no surviving information on the shape or proportions of these churches; the last remnants were demolished at the turn of the 18th and 19th century. The golden age of the wooden churches was presumably in the 17 th and 18th centuries, they were defining buildings in this transition period. ${ }^{12}$

The ideas of the Reformation seemingly conquered the area of Sepsiszentgyörgy within 50-100 years. However, it took over 400 years, considering the changes in the layout, design, all the furnishing and appliances, for the complete transformation of the churches of Sepsiszék. Not independent from international tendencies, they evolved in their own way in proportions and appearance. Layouts other than the elongated nave with a polygonal recess and the simple rectangular floor plan cannot be found here in Sepsiszék. This formula - with minor alterations in form and proportions - enriched with the knowledge rooted in the vernacular architecture and sometimes supplemented with details from certain style periods, made it possible for churches suitable for both community and religion to emerge and to serve the congregations throughout centuries.

11 János Laczkovics helped in determining the age of the roof structure.

12 More information about the relics of Transylvanian wood architecture can be found in Ilona Balogh's writings, where the belfry of Kálnok from the discussed region is also mentioned. These writings draw attention to the fact that these Transylvanian wooden structures are singularly independent from the historical styles and are the most devoted to the traditional, elemental forms. Balogh, I. 1935. According to Vámos and Bibó, the prefigurations of these wooden churches could have been the timber houses (Vámos, 1936; Bibó, 1967 p. 542.). According to the author, they are also related to the outbuildings of the houses - also built by local craftsmen - holding - as mentioned - larger and more meticulous structural details.

\section{Evaluation}

After broadly describing the architectural tools, it is worth reviewing the most determinant tendencies in space formation, which appeared in the 16th-19th century Sepsiszék. (Fig. 11)

As can be deduced from the previous observations, mainly the spatial forms, spatial proportions and the layout of the interior were the determinative elements in the development during the particular periods. When analysing the spatial proportions, it is clear that the values of the length/width and height/width ratios of the churches decreased gradually and continuously.

The direction of the spatial formation can be described with the undulating alternation between two tendencies. The first tendency includes the buildings that kept the traditional spatial and mass formation. An example of this group, the churches preserved in their medieval, Gothic form, or the Gothic Revival-style churches from the late 19th century, is the Calvinist church of Sepsiszentkirály. These buildings are the retrospective elements of Protestant church architecture, as they all kept the sanctuary - slightly separate from the main nave. From a spatial use perspective, the pulpit placed on the triumphal arch can be interpreted as a significant act of moving towards a centralising use of the space; however, in the case of churches built after the Patent of Tolerance, this is more of an archaising manner. Churches with a layout defined by a longitudinal axis follow Catholic traditions, however, the layout of the sanctuary - due to the regular layout of the Calvinist liturgy - had to follow a centralising composition.

Representing the second defining tendency are the buildings built following the Reformation. Those 19th-century churches imitate not only the sanctuary but have a strongly centralising layout as well as - knowing its former layout and structure the church of Maksa. The churches of this tendency are forward-looking, as they try to shape the layout and form of the church according to the liturgy. The did not break completely with Roman Catholic architectural traditions but tried to give an architectural response to the existing spatial formation problems by adapting to the Calvinist spatial needs and not rejecting, but reinterpreting traditions. This architectural response was initially the centralising layout, then the excessive reduction of the sanctuary-form and the reduction of the proportional values of the space.

Besides the two, continuously alternating tendencies, distinctive, parallel tendencies can also be interpreted. These include all churches with a rectangular floor plan as well as the church of Réty with its " $T$ "-shaped layout.

Rebuilding to a rectangular form was a tendency that applied from the beginning of the 19th century in the case of medieval churches. The already built early rectangular-shaped churches could have been models for these interventions. It is worth observing the location of these buildings. It can be clearly seen that such churches - either built or rebuilt with a rectangular floor plan - are only found in the Northeastern part of Sepsiszék. 
PROPORTION OF LITURGICAL SPACES IN TIME

(B/A)

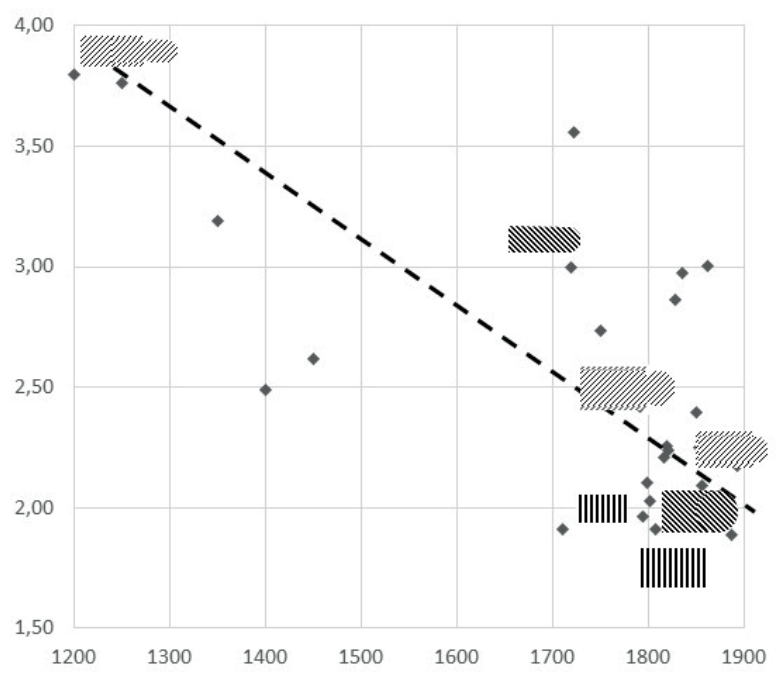

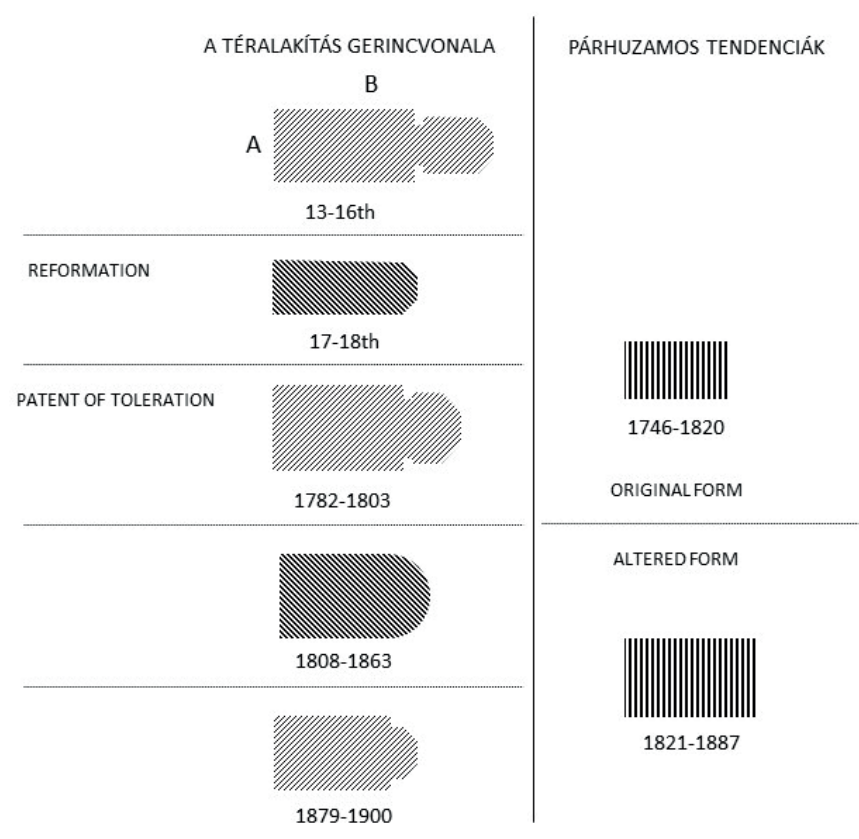

Fig. 11 Different types of liturgical spaces layouts found in the Calvinist churches of Sepsiszék and a diagram showing their development through time.

This is a local tendency within the region. The reasons behind this phenomenon may be found through further research.

Another local trend in Sepsiszék is the existence of the longitudinal use of space. Such buildings can be found in one group in Northern Sepsi (Oltszem, Bodok). It cannot be ignored that these villages were in the possession of the Mikó family - along with other villages such as Mikóújfalu that were settled with Roman Catholic peasant families. Thus, a baronial influence could be a possible reason behind this practice. Additionally, these villages are next to the neighbouring region, Csíkszék, which has a strong Roman Catholic background. This could have also had an influence on the church architecture of the area.

The other two churches with a longitudinal layout - Kökös and Maksa - also should be mentioned. In the case of Maksa, it is known that the church previously had a centralising layout. Regarding Kökös, it is a church built in the period following the Patent of Tolerance, at the southern borderland of Sepsiszék. In the latter case, the geographical location - the proximity of the monumental Saxon fortified churches such as the ones in Prázsmár and Szászhermány - is responsible for the possible influence of Lutheran church architecture.

The church of Réty follows a "T"-shaped spatial use. Although the church is unique in Sepsiszék, it can be pointed out that this use is originated from the southern portico and it is a necessary linkage to the liturgical space. Several examples of this use are known throughout the Háromszék region and also in Western Europe, relatable to works from architects like L. C. Sturm (1712; 1718).

The other truly interesting observation regarding spatial use - related to the " $\mathrm{T}$ "-shaped form - is connected to the transversal use of the churches. The doctoral dissertation of Kathrin Ellwardt (2004), about the "Querkirchen", can be paralleled with the centralising tendencies of the spatial use of the churches in Háromszék. In most cases, space is organised around the pulpit placed in the middle of the northern wall. It is further observable that these churches often have pews rotated 90 degrees, which act inserts a transversal spatial use in a simple rectangle. In other words, it is a " $\mathrm{T}$ "-shaped layout, but the "leg" of the " $T$ " is pulled back into the rectangular layout. Considering this method, it can be concluded that the churches of Sepsiszék and Háromszék show similarities to the interior spatial structures of the "Querkirchen".

Altogether, in can be concluded that the duality of spatial forming roughly follows the tendencies occurring in other parts of Greater Hungary. Its direction can be fitted into the path evolving throughout the centuries, one that leads from the spatial forming preserving medieval traditions, but focusing on the pulpit, to spatial concepts that are significant in Reformed church architecture on a European level as well. The significance of the researched churches of Sepsiszék in architecture history is defined by the duality, the innovative spirit as well as the strong fidelity to traditions.

By discussing the church architecture of Sepsiszék, a so far poorly explored field of the former Greater Hungary's history of Reformed church architecture has been touched. The evaluation of the topic is complex, as the churches in question have unique life paths of their own. Nonetheless, the author has tried to direct the reader's attention towards the values beyond the buildings' own existence.

The discussed churches of this remote region are valuable pieces of the history of sacral architecture in Hungary and Europe. Beyond the local autochthon qualities, universal tendencies also appear in their evolution. Due to their often seemingly neutral, simple appearance - which can be traced back to the 
deficiencies of architectural details - greater architectural contexts such as spatial forms and spatial proportions tend to be left forgotten, although, besides the layouts of the interiors, attempts accommodating to the Calvinist liturgy are also expressed.

\begin{tabular}{|c|c|c|}
\hline \multicolumn{3}{|c|}{ Hungarian - Romanian - German / Saxon Dictionary } \\
\hline Csíkszék & Ciuc Scaune & - \\
\hline Háromszék & Trei Scaune & - \\
\hline Kézdiszék & (Kezdi Scaune) & - \\
\hline Orbaiszék & (Orbai Scaune) & - \\
\hline Sepsiszék & (Sepsi Scaune) & - \\
\hline Miklósvárszék & (Miclăuș Scaune) & - \\
\hline Brassó & Brașov & Kronstadt/Kruhnen \\
\hline Dálnok & Dalnic & - \\
\hline Köpec & Căpeni & - \\
\hline Magyarhermány & Herculian & Hermansdorf \\
\hline Prázsmár & Prejmer & Tartlau/Tuartlen \\
\hline Szászhermány & Hărman & Honigberg/ \\
\hline & & Huntschprich \\
\hline Aldoboly & Dobolii de Jos & - \\
\hline Angyalos & Angheluş & - \\
\hline (Sepsi)Árkos & Arcuș & - \\
\hline Bikfalva & Bicfalău & - \\
\hline Bita & Bita & - \\
\hline Egerpatak & Aninoasa & - \\
\hline Eresztevény & Eresteghin & - \\
\hline Étfalva & Etfalău & - \\
\hline Fotosmartonos & Fotoș & - \\
\hline Gidófalva & Ghidfalău & - \\
\hline Illyefalva & Ilieni & Ilgendorf \\
\hline Kálnok & Calnic & - \\
\hline (Sepsi)Kilyén & Chilieni & Kilön \\
\hline Komolló & Comolău & - \\
\hline Kökös & Chichiş & - \\
\hline Lisznyó & Lisnău & - \\
\hline Maksa & Moacșa & - \\
\hline Málnás & Malnaş & - \\
\hline Oltszem & Olteni & Altzen \\
\hline Réty & Reci & - \\
\hline Sepsibesenyő & Păduren & - \\
\hline Sepsibodok & Bodoc & - \\
\hline Sepsikőröspatak & Valea Crișului & - \\
\hline Sepsimagyarós & Măgheruş & - \\
\hline Sepsiszentgyörgy & Sfântu Gheorghe & Sankt Georg/Gergen \\
\hline Sepsiszentkirály & Sâncraiu & - \\
\hline Szacsva & Saciova & - \\
\hline Szemerja & - & - \\
\hline Szotyor & Coșeni & - \\
\hline Uzon & Ozun & Usendorf \\
\hline Zalán & Zălan & - \\
\hline Zoltán & Zoltan & - \\
\hline
\end{tabular}

\section{References}

Balogh, I. (1935) Magyar fatornyok. Karcag, Kertész Ny. (in Hungarian) Bibó, I. (1967) Az Alföld késő barokk és klasszicista építészetének néhány kérdése. Épités- és Közlekedéstudományi Közlemények. 9(3-4), pp. 525564. (in Hungarian)

Bibó, I. (1984) Der protestantische Kirchenbau in Ungarn um 1800, 1.Teil. Mitteilungen der Gesellschaft für vergleichende Kunstforschung in Wien. Gesellschaft für Vergleichende Kunstforschung. 36(3), pp. 1-2. (in German)

Buzogány, D., Sipos, G. (szerk.) (2005). - A Sepsi Református Egyházmegye vizitációs jegyzőkönyvei 1728-1790. In: Erdélyi református egyháztörténeti adatok 3. Kolozsvár, EREA. (in Hungarian)

Danielisz, D. (2015) Sepsiszéki református templomok téralakitása a XVIXIX. században. Tudományos Diákköri dolgozat. Budapesti Müszaki és Gazdaságtudományi Egyetem. Építészettörténeti és MűemlékiTanszék. Építészettörténeti szekció. (in Hungarian)

Danielisz, D. (2016) Ülésrend és térhasznált Sepsiszék református templomaiban. Architectura Hungariae. 15(3), pp. 147-156. (in Hungarian)

Ellwardt, K. (2004) Kirchen bauzwischen evangelischen Idealen und absolutistischer Herrschaft. Die Querkirchen im hessischen Raum von Reformationsjahrhundert bis zum Sieberjährigen Krieg. Universität Marburg, Dissertation (2000), Michael Imhof Verlag, Petersberg. (in German)

Marosi, E. (1992). Magyar református templomok. Mủvészettörténeti áttekintés. In: Református templomok Magyarországon. (Dercsényi, B., Hegyi, G., Marosi, E., Takács, B. (eds.)). Budapest, Hegyi és társa Kiadó. (in Hungarian)

Mihály, F. (2008) Adatok az erdélyi éneklőszékek kutatásához. Református Szemle 101(4), pp. 377-410. (in Hungarian)

Ösz, S. E. (2008). Éneklőpulpitusok az erdélyi református gyülekezetekben. Magyar Egyházzene. 15(3), pp. 287-334. (in Hungarian)

Sturm, L. C. (1712) Architectonisches Bedencken von protestantischer kleinen Kirchen Figur und Einrichtung. Hamburg. (in German)

Sturm, L. C. (1718) Vollständige Anweisungalle Arten von Kirchen wohl anzugeben. Augsburg. (in German)

Vámos, F. (1936) Magyar faépítészet. Magyarságtudomány. 2, pp. pp. 273289. (in Hungarian) 